\title{
EPIDEMIOLOŠKE I KLINIČKE KARAKTERISTIKE CISTIČNE FIBROZE U ODRASLOJ DOBI
}

\author{
Olivera Ljuboja' Dragana Malčić Zanić
}

\begin{abstract}
Sažetak
Danas zahvaljujući identifikaciji mutacija koje dovode do cistične fibroze, nastanka bolesti, omogućeno je istraživanje o povezanosti vrsta mutacije (genotip) i njihove kliničke ekspresije (fenotip) kod oboljelih. Uprkos dijagnostičkim kriterijima, dijagnoza CF-a nije uvijek laka, pogotovo u odrasloj dobi kad se bolest može prezentovati varijabilnim fenotipom. Danas djeca rođena sa cističnom fibrozom doživljavaju odraslu dob, sa očekivanom medijanom preživljavanja od 50 godina. Produžavanje životnog vijeka u odraslu dob suočava bolesnike $s$ novim terapijskim potrebama, a doktore $s$ novim prezentacijama i komplikacijama bolesti. Sa prelaskom bolesnika iz dječije u odraslu dob javljaju se nova klinička stanja i komplikacije bolesti koje zahtijevaju poseban oblik zbrinjavanja $i$ pružanja specifične zdravstvene njege koju više nije moguće pružiti u postojećem pedijatrijskom okruženju. Tada govorimo o procesu tranzicije ili prelaska bolesnika iz pedijatrijske u adultnu brigu. Tranzicija je multidisciplinarni $i$ aktivni proces za bolesnika veoma stresan te je neophodo posvetiti veliku pažnju psihosocijalnim i obrazovnim potrebama mladog bolesnika.
\end{abstract}

Ključne riječi: cistična fibroza, odrasli bolesnici

\section{Uvod}

Cistična fibroza (CF) najčešća je autosomno recesivno nasljedna multisistemska bolest bijele rase. Gen čija mutcija dovodi do nastanka bolesti nalazi se na dugom kraku 7. hromozoma i kodira sintezu polipeptidnog lanca, odnosno proteina koji je nazvan CFTR (Cystic Fibrosis Transmembrane Condunctance Regulator).

Ovaj protein učestvuje $\mathrm{u}$ aktivnom transportu elektrolita kroz ćelijsku membranu epitelnih ćelija žlijezda koje se nalaze u respiratornom, digestivnom i reproduktivnom sistemu. Mutacije u CFTR genu dovode do narušavanja strukture i funkcije CFTR proteina kao jonskog kanala, što za posljedicu ima poremećaj transporta natrijuma, hlora, bikarbonata $\mathrm{i}$ vode. Zbog ovog defekta je sekret koji produkuju pomenute žlijezde gust, viskozan i dovodi do opstrukcije izvodnih kanala, što uzrokuje oštećenje tkiva u navedenim sistemima.

Dosadašnja otkrića vezana za molekularnu osnovu nastanka CF su omogućila da analiza DNK na mutacije u genu za CFTR danas postane jedna od najčešće korišćenih postupaka u dijagnozi ove bolesti. Zahvaljujući identifikaciji mutacija koje dovode do nastanka bolesti, omogućeno je istraživanje o povezanosti vrsta mutacije (genotip) i njihove kliničke ekspresije (fenotip) kod oboljelih. Do danas je detektovano oko 1900 mutacija. U skladu sa rezultatima u dosadašnjoj literaturi, očekivano najčešća mutacija je F508del, ona je utvrđena kod skoro $70 \%$ oboljelih. Pored ove mutacije, svega četiri mutacije imaju učestalost od preko 1\% (G542X, N1303K, G551D i W1282X), dok za ostale mutacije učestalost iznosi $0.1-1 \%$ oboljelih (1).

Uprkos dijagnostičkim kriterijima, dijagnoza CFa nije uvijek laka, pogotovo u odrasloj dobi kad se bolest može prezentovati varijabilnim fenotipom, s toga dijagnoza CF ostaje u prvom redu klinička dijagnoza. Klinička slika može biti klasična i atipična. Klasična klinička slika CF obuhvata 4 osnovne prezentacije (pojedinačno ili u kombinaciji): hroničnu plućnu bolest, gastrointestinalne simptome, sindrome gubitka soli i mušku neplodnost. Nasuprot tome atipični oblici bolesti obično su praćeni održanom funkcijom pankreasa, blagog su kliničkog toka, obično se prepoznaju kasnije u adolescenciji ili odrasloj dobi, a dijagnoza može biti otežana nejasnim ili dvosmislenim dijagnostičkim nalazima. Posebna grupa bolesnika je ona koja se ne uklapa $u$ dijagnostičke kriterije za CF. Tu susrećemo normalne ili intermedijalne vrijednosti hlorida $u$ znoju, jednu CFTR mutaciju te često manifestaciju 
bolesti samo na jednom organskom sistemu. Takve manifestacije označavamo kao bolesti $\mathrm{s}$ poremećajem CFTR funkcije (engl. CFTR related disease). Ishod bolesnika s takvom manifestacijom $\mathrm{u}$ odnosu na tipičnu bolest značajno je bolji, zbog čega ih je važno i klinički razlikovati. Danas zahvaljujući boljem razumijavanju patogeneze same bolesti, ali i napretku dijagnostičkih $\mathrm{i}$ terapijskih intervencija u toku same bolesti, djeca rođena sa CF-om većinom doživljavaju odraslu dob, sa očekivanom medijanom preživljavanja od 50 godina (2). Uvidom u američki registra bolesnika sa CFom utvrđen je porast odraslih bolesnika od 1982. do 2007. godine sa $27 \%$ na $56 \%$ (3). Prema podacima kanadskog registra bolesnika je vidljivo da je od 1990.do 2012 godine medijan preživljavanja sa 31,9 (95\% CI 28.3-35.2 godina) ) povećan na 47,7 godina (95\% CI 46.1-52.2 godina). Produžavanje životnog vijeka u odraslu dob suočava bolesnike $\mathrm{s}$ novim terapijskim potrebama, a doktore s novim prezentacijama i komplikacijama bolesti. Klasična klinička prezentacija $\mathrm{CF}$ je hronična plućna bolest prisutna kod gotovo svih bolesnika. Faktori rizika koji doprinose smanjenju plućnih funkcija (forsirani ekspiratorni volumen u $1 \mathrm{~s}$, FEV1), u odraslih bolesnika su indeks tjelesne mase (BMI), hronična kolonizacija sa Pseudomonas aeruginosa, insuficijencija pankreasa i dijabetes u CF (CFRD). Pacijenti sa nižim BMI imaju $\mathrm{FEV}_{1}<40 \%$. Hronična kolonizacija disajnih puteva sa Ps. aeruginosom 2.4 puta povećava rizik za tešku respiratornu insuficijenciju. Ovaj rizik kod bolesnika sa insuficijencijom pankreasa $\mathrm{i}$ manifestnim dijabetesom iznosi 2 odnosno 1.8. (5). Sa napredovanjem plućne bolesti, uz prisutnu hroničnu kolonizaciju Ps. aeruginosom dolazi do naseljavanja disajnih puteva i drugim patogenima: Staphaphilococcus aureus (21- 61\%), Haemophilus influenzae (0-22\%), Burkholderia cepacia (1,7-23\%) i Stenotrophomonas maltophilia. (1,1-22\%). Od drugih plućnih komplikacija javljaju se bronhopulmonalna aspergiloza kod 9-10\%, hemoptizije $9 \%$, spontani pneumotoraks $18 \%$ čime se i do dva puta povećava stopa smrtnosti (6). Sa napredovanjem plućne bolesti razvijaju se peribronhalna fibroza i bronhiektazije koje se obično prvo nalaze u gornjim režnjevima pluća i konačno supurativna opstrukcijska bolest praćena čestim egzacerbacijama i progresivnim gubitkom plućne funkcije. Hronična respiratorna insuficijencija vodi u plućnu hipertenziju. Plućnu hipertenziju karakterišu povišeni pritisci u plućnoj arteriji (sistolni pritisak u plućnoj arteriji iznad 30 $\mathrm{mm} \mathrm{Hg}$, dijastolni iznad $10 \mathrm{~mm} \mathrm{Hg}$ i srednji pritisak iznad $20 \mathrm{~mm} \mathrm{Hg}$ ), povišena plućna vaskularna rezistencija i klinički znaci popuštanja desnog srca zbog naknadnog opterećenja (afterload)(7). Transplantacija pluća je terapijski izbor kod progresivne respiratorne insuficijencije. Procjena stanja bolesnika i izbor pravog trenutka za transplantaciju izuzetno su važni jer bolesnici moraju imati koristi od transplantacije $u$ preživljavanju. Kriteriji za transplantaciju kod CF-a uključuju: FEV1 $\leq 30 \%$, BMI manji $22 \mathrm{~kg} / \mathrm{m} 2$, povećani broj hospitalizacija, masivne hemoptizije, pCO2 $>55 \mathrm{mmHg}$ ili pO2 $\leq 55 \mathrm{mmHg}$. Obzirom na navedeno, poseban akcenat je na dobroj predtransplantacijskoj pripremi i posttransplantacijskoj njezi kako bi uspješnost transplantacije i kvaliteta života transplantiranog bolesnika bila što bolja, a preživljavanje što duže (8). Što bolesnici sa CF žive duže uz plućne komplikacije sve više dolaze do izražaja i komplikacije na drugim organskim sistemima. Najčešća klinička manifestacija bolesti pankreasa je nedovoljna egzokrina sekrecija. Ona je dio kliničke slike između 85 i $90 \%$ bolesnika s CF, a praktično svih sa mutacijom $\Delta \mathrm{F} 508$. U literaturi se ovi bolesnici obično označavaju slovima PI (prema engl. ,pancreatic insufficient"), za razliku od tzv. PS bolesnika (prema engl. ,pancreatic sufficient") koji čine $15 \%$ imaju „dostatnu količinu enzima pankreasa“, što omogućuje subnormalnu sekreciju masti i bjelančevina. 20\% PS bolesnika tokom vremena ima jednu ili više epizoda pankreatitisa. Pankreatitis je druga važna klinička manifestacija poremećaja egzokrinog dijela pankreasa prisutna kod oko $2 \%$ bolesnika sa CF, odnosno kod $10-14 \%$ bolesnika sa ranije očuvanom funkcijom pankreasa. Češći je kod starije djece, adolescenata i odraslih bolesnika, a obično je povezan $\mathrm{s}$ blažim nepravilnostima CFTR proteina, odnosno blažim mutacijama, lakšim oblikom bolesti s blažim respiratornim simptomima (9). Bolesnici stvaraju dovoljno enzima i nemaju malapsorpciju (PS bolesnici) (10). Dijagnoza akutnog pankreatitisa (AP) kod ovih bolesnika postavlja na osnovu prisustva dva od tri data kreterijuma: akutna abdominalna bola sa ili bez povraćanja, trostruko povišene vrijednosti amilaza i/ili lipaza u serumu, 
radiološki nalaz koji govori u pravcu pankreatitisa. Dve ili više epizoda akutnog pankreatitisa sa potpunom normalizacijom kliničkog stanja između njih se označava kao akutni rekurentni pankreatitis (ARP). Pankreatitis može biti i hroničnog toka. 18\% PS pacijenata će razviti jednu epizodu AP, dok će njih $60 \%$ imati ARP, a $22 \%$ hronični pankreatitis. Smatra se da sve osobe sa ponavljanim ,,idiopatskim, ARP treba ispitivati u pravcu CF ukoliko već nemaju potrvđenu dijagnozu. Hronični pakreatitis tokom vremena povećeva rizik za nastanak karcinoma pankreasa, o čemu je potrebno misliti tokom praćenja ovih bolesnika (11). S vremenom dolazi do propadanja funkcije i endokrinog dijela pankreasa, usljed čega dolazi do slabijeg lučenja inzulina i inzulinske rezistencije, a kao rezultat toga nastaje dijabetes mellitus povezan sa cističnom fibrozom, (CFRD, prema engl. CFrelated diabetes). Učestalost CFRD-a u dobi iznad 40 godina iznosi oko $40-50 \%$, a preostlih $30 \%$ ima poremećaj tolerancije glukoze. CFRD se češće javlja kod ženskog pola, kod nosilaca težih mutacija , kod bolesnika sa jetrenom bolesti. Prema vodičima za CF preporučuje se godišnje odrediti test tolerancije glukoze kod svih pacijenata starijih od 10 godina. Zlatni standard za dijagnozu CFRD se zasniva na OGTT testu i vrijednostima $\mathrm{Hg}$ A1C veće ili jednako 6\%. Dugotrajna bolest uz lošu kontrolu CFRD-a praćena je pojavom mikrovaskularnih komplikacija od dijabetičke retinopatije, neuropatije te mikroalbuminurije kao posljedice nefropatije (12).

Sveprisutan poremećaj metabolizma kostiju je jedan od značajnih komorbiditeta odraslih bolesnika sa CF (engl. CF bone disease,CFBD) . Još 1979 Mischler i sar. su opisali prisustvo niske gustine kostiju kod ovih bolesnika. Učestalost osteoporoze je oko $23.5 \%$, a osteopenije oko $38 \%$. CFBD je primjer multifaktorskog poremećaja, koji je uzrokovan nedostatkom vitamina $\mathrm{D}$, ishranom, hipogonadizmom, povećanim upalnim citokinima $\mathrm{i}$ glukokortikoidnim terapijama. Muški pol, uznapredovala plućna bolest, neuhranjenost su dodatni faktori rizika za CFBD. Glavna klinička manifestacija osteoporoze su spontane frakture kostiju koje ometaju redovnu položajno-perkusionu drenažu grudnog koša što doprinosi pogoršanju plućnih funkcija. Fondacija CF trenutno preporučuje da se svim osobama sa CF starijim od 18 godina učini osteodenzitometrija (DXA). Pacijentima sa normalnom koštanom gustinom retestiranje se ponavlja svakih pet godina. Ako je DXA Z-skor $<-1$ ali $>-2$, testiranje treba ponavljati svake $2-4$ godine. Na kraju, ako je Z-skor manji ili jednak -2, potrebno je liječiti osteoporozu, a DXA procjena se ponavlja svake godine (13). Hronična inflamacija doprinosi nastanku epizodnih artritisa koji se javljaju početkom adolescencije i nisu vezani za težinu plućne bolesti. Nasuprot tome, hipertrofična pulmonalna osteoartropatija se javlja kod odraslih pacijenata, težeg je kliničkog toka i povezana je sa uznapredovalom plućnom bolesti i njenim pogoršanjem. U tvrdokornim slučajevima pored terapije nesteroidnim antiinflamatornim lijekovima $\mathrm{i}$ steroidima zahtijeva primjenu bifosfanata $(2,14)$.

Kako u opštoj populaciji tako i kod bolesnika sa CF sa starenjem raste rizik za nastanak maligniteta. Abdul-Karim i saradnici su 1982. godine prvi opisali pojavu maligniteta kod CF bolesnika (15). Prema podacima Američkog registra za $\mathrm{CF}$ maligne bolesti su registrovane kod 172 netransplantirana bolesnika sa CF umjesto očekivanih 153,5. Standardizovani omjer incidence (SIR) za tumore gastrointestinalnog trakta je bio najveći 17,5 , sa predominacijom tumora kolona i tankog crijeva ( SIR 6,2 odnosno 11,5). Ovi tumori su se javljali češće kod bolesnika koji su imali predhodnu distalnu intestinalnu opstrukciju, sklerozirajući holangitis, gastroezofagealnu refluksu bolest, inflmatornu bolest crijeva, kao i kod nosilaca teških mutacija (homozigoti deltaF508). Prisustvo deltaF508 je predstavljalo faktor rizika i za nastanak tumora testisa sa SIR 3,0. Česta izloženost zračenju tokom radiografskih snimanja dovodila se u vezu sa nastankom akutnih leukemija, limfoma, karcinoma štitnjače i bubrega, ali u studiji Maisonneuvea i saradnika nije dokazan apsolutni porast ovih maligniteta $u$ odnosu na osobe bez CF. Usljed primjene imunosupresivne terapije incidenca tumora gastrointestinalnog trakta i limfoma je još i veća kod transplantiranih (16).

Visoka učestalost tumora gastrointestinalnog trakta, nalaže redovan skrining visokorizičnih grupa bolesnika u pravcu ranog otkrivanja ovih maligniteta. Kolonoskopija se predlaže kod svih bolesniak sa CF starijih od 40 godina u trogodišnjim razmacima, kod transplantiranih već od 30-te godine života. Nasuprot pomenutog povećanog rizika za nastanak tumora, u nekoliko studija je utvrđeno da mutacija deltaF508 ima protektivni uticaj za 
nastanak malignog melanoma, sa smanjenjem rizika od $80 \%(16,17,18)$.

Činjenica je da za adultne doktore bolesnici s cističnom fibrozom predstavljaju veliki izazov. Sve donedavno pulmolozi (kao i drugi specijalisti adultne medicine) nisu se susretali sa ovom grupom bolesnika, kao niti sa svim mogućim komplikacijama bolesti. S prelaskom iz adolescencije u odraslu dob pojavljuju se i pitanja i dileme vezane za mogućnost osnivanja porodice, ostvarenja trudnoće, odnosno ostvarivanja kao roditelja kod ovih bolesnika. Mnoge žene s cističnom fibrozom (CF) su sposobne da zatrudne, podnose trudnoću dobro i imaju povoljne ishode trudnoće, prema novim istraživanjima. Međutim, kao što je dr Chad A. Grotegut rekao : "Budući da se podaci dobivaju iz administrativne baze podataka, teško je znati koje žene s cističnom fibrozom će biti dobro, a koje će imati negativan ishod." Prva trudnoća žene sa CF je bila 1960. godine, od tada je primjećen značajan linearni porast prevalencije CF na porodu od 3,0 do 9,8 na 100.000 porođaja između 2000. i 2010.g. Sjedinjene Američke drževe (SAD) u svom registru imaju 13.095 prijavljenih oboljelih od CF. U period od 2008 do 2010. g., bilo je 1.119 porođaja žena $\mathrm{s} C F \mathrm{u}$ poređenju $\mathrm{s}$ više od 12,6 miliona žena bez bolesti. Tokom poroda 11 žena s CF je umrlo, to čini rodiljni mortalitet od oko 1000 na 100.000 poroda, dok u žena bez CF 7,3 umrlih na 100.000 poroda. Starost žena sa CF se kretala $14-45$ godina, $25 \%$ poroda se desio prije 37 nedelje gestacije. Majke su imale znatno veću mogućnost smrtnog ishoda po završetku poroda zbog pogoršanja plućne bolesti $(56,6)$, njih 18,3 zahtijevalo je mehaničku ventilaciju, dok je 17,3 imalo akutnu bubrežnu insuficijenciju. U planiranju trudnoće kod bolesnica sa CF moraju se poštovati tzv. prediktori za predviđanje ishoda CF trudnoće, a to su plućna funkcija prije trudnoće (FEV1 $\geq 60 \%)$, mikrobiološki status (kolonizacija - Burkhodleria cepacia), nutritivni status (BMI od $22 \mathrm{~kg} / \mathrm{m} 2$ ), diabetes mellitus (CFRD). Praćenjem navedenih prediktora pokušava se maksimizirati šanse za bezbjednu trudnoću i smanjiti rizik za javljanje komplikacija, a time negativan ishod po porodilju.

\section{Zaključak}

Iz svega nevedenog do sada vidimo da prelaskom iz dječije u odraslu dob javljaju se klinička stanja i nastanak novih poteškoća koje zahtijevaju poseban oblik zbrinjavanja ovih pacijenat te pružanja specifične zdravstvene brige koju više nije moguće pružiti u postojećem pedijatrijskom okruženju. Tada govorimo o procesu tranzicije ili prelaska bolesnika iz pedijatrijske u adultnu brigu. Tranziciju možemo posmatrati kao planirani i strukturirani prelaz hroničnoga pedijatrijskog bolesnika na adultnu zdravstvenu brigu. To je prije svega proces u kom se adolescenti $\mathrm{s}$ cističnom fibrozom pripremaju za samostalnu brigu o svom zdravlju i životu, kada briga (ali i odgovornost) postepeno prelazi $\mathrm{s}$ roditelja na bolesnika. Tranzicija je multidisciplinarni i aktivni proces gdje se posvećuje velika pažnja i psihosocijalnim i obrazovnim potrebama mladog bolesnika.

\section{Literatura}

1. CFGCA (Cystic Fibrosis Genetics Analysis Consortium). The CFTR Mutation Database. Dostupno na: http://www3.genet.sickkids.on.ca/cftr/app

2. Do.Tješić-Drnković, L.Omerza,Du.Tješić-Drinković, S.Kelečić, D.Čaleta. Osobitosti cistične fibroze u adolescentnoj i odrasloj dobi. Pediatr. Croat. 2014; 58(1):66-71.

3. Cystic Fibrosis Foundation Patient Registry Annual Data Report. Cystic Fibrosis Foundation: 2008 Bethesda, USA.

4. Stephenson AL, Tom M, Berthiaume Y, et al. A contemporary survival analysis of individuals with cystic fibrosis: a cohort study. Eur Respir J. 2015; 45:670-679.

5. Kerem E, Viviani L, Zolin A, MacNeill S, Hatziagorou E, Ellemunter H, Drevinek P, Gulmans V, Krivec U, Olesen H; ECFS Patient Registry Steering Group. Factors associated with FEV1 decline in cystic fibrosis: analysis of the ECFS Patient Registry.

6. Eur Respir J. 2014; 43(1):125-33.

7. Flume PA. Pulmonary complications of cystic fibrosis. Respir Care. 2009; 54(5):618-27.

8. Eckles M, Anderson P. Cor pulmonale in cystic fibrosis. Semin Respir Crit Care Med. 2003; 24(3):32330.

9. Hadjiliadis D. Special considerations for patients with cystic fi brosis undergoing lung transplantation. Chest. 2007;131:1224-31.

10. De Boeck K, Weren M, Proesmans M, Kerem E. Pancreatitis among patients with cystic fibrosis: 
correlation with pancreatic status and genotype. Pediatrics. 2005;115:463-9.

11. Noone PG. Zhou Z. Silverman LM. Jowell PS. Knowles MR. Cohn JA. Cystic fibrosis gene mutations and pancreatitis risk: relation to epithelial ion transport and trypsin inhibitor gene mutations. Gastroenterology. 2001; 121:1310-9.

12. Jay F., Chee Y. Ooi Pancreatitis and pancreatic cystosis in Cystic Fibrosis. Journal of Cystic Fibrosis. 2017; S79-S86.

13. Chan CL, Vigers T, Pyle L, Zeitler PS, Sagel SD, Nadeau KJ. Continues glucose monitoring abnormalities in cystic fibrosis youth correlate with pulmonary function decline. J Cyst Fibros. 2018; 17(6):783-790.

14. Mathiesen IH, Pressler T, Oturai P, Katzenstein TL, Skov M, Frikke-Schmidt R, Hitz MF.Osteoporosis Is Associated with Deteriorating Clin ical Status in Adultswith Cystic Fibrosis. Int $\mathrm{J}$ Endocrinol. 2018.

15. Stalvey MS, Clines GA. Cystic Fibrosis-Related Bone Disease: Insights Into a Growing Problem. Curr Opin Endocrinol Diabetes Obes. 2013; 20(6): 547-552.

16. Abdul-Karim FW, King TA, Dahms BB, Gauderer MW, Boat TF. Carcinoma of extrahepatic biliary system in an adult with cystic fibrosis. Gastroenterology. 1982;82(4):758-762.

17. Maisonneuve P, Marshall BC, Knapp EA, Lowenfels AB. Cancer Risk in Cystic Fibrosis: A 20-Year Nationwide Study From the United States. J Natl Cancer Inst 2013;105:122-129.

18. Hadjiliadis D, Khoruts A, Zauber AG, Hempstead SE, Maisonneuve P, and Lowenfels AB; On behalf of the Cystic Fibrosis Colorectal Cancer Screening Task Force Cystic Fibrosis Colorectal Cancer Screening Consensus Recommendations. Gastroenterology 2018;154:736-745.

19. Gini A, Zauber AG, Cenin DR, Omidvari AH, Hempstead SE, Fink AK, Lowenfels AB, Lansdorp-Vogelaar I. Cost Effectiveness of Screening Individuals With Cystic Fibrosis for Colorectal Cancer. Gastroenterology. 2018;154(3):556567.

20. Niccum DE, Billings JL, Dunitz JM, Khoruts A. Colonoscopic screening shows increased early incidence and progression of adenomas in cystic fibrosis. J Cyst Fibros. 2016;15(4):548-53.

21. J Geake. Pregnancy and cystic fibrosis: Approach to contemporary management. Obstet Med. 2014. 7(4): 147-155.

\begin{abstract}
Today, due to the identification of mutations causing the cystic fibrosis, the onset of the disease, research into the relationship between types of mutation (genotype) and their clinical expression (phenotype) in patients has been made possible. Despite the diagnostic criteria, CF diagnosis is not always easy, especially in adulthood when the disease can be presented with a variable phenotype. Today children born with cystic fibrosis experience an adult age, with the expected median survival of 50 years. Extension of lifespan in adulthood faces patients with new therapeutic needs, and doctors with new presentations and complications of the disease. With the transition of children from adolescence to adulthood, new clinical conditions and complications of a disease arise which require a special form of care and provision of specific health care that can no longer be provided in the existing pediatric environment. I that case we are talking about the process of transition of patients from pediatric to adult care. Transition is a multidisciplinary and active process for patients and very stressful therefore it is necessary to pay great attention to the psychosocial and educational needs of a young patient.
\end{abstract}

Key words: cystic fibrosis, adult patient

\author{
Mr sci dr Olivera Ljuboja \\ pedijatar pulmolog \\ Tel: $+387 / 51 / 342-429$ \\ Mobtel +387/65/527098 \\ Email: olivera.ljuboja@gmail.com
}

